\title{
Residential Density And Healthy Homes With Respiratory Events On Toddlers In The Working Area Clinics Pekauman
}

\author{
Fadhiyah Noor Anisa ${ }^{1}$, Susanti Suhartati ${ }^{2}$, Nursaupiah ${ }^{3}$ \\ \{ Fadhiyah.n.anisa@gmail.com\} \\ Diploma of Midwifery Faculty of Health Sari Mulia University, Scout Road No.2 of \\ Banjarmasin, South Kalimantan
}

\begin{abstract}
Respiratory tract infections in the region Banjarmasin South as much as 5,023 cases $(15.6 \%)$. There are 328 Genesis respiratory tract infections on babies within one year in the region, there are Pekauman Clinics 44 families with toddlers, there are 10 pieces of homes inhabited by 10 families, a total of 6 houses inhabited by more than one family. Most families live in tenement. The purpose of the research relationship residential density and healthy homes with the incidence of respiratory tract infections in Toddlers work Clinics Pekauman relic in Banjarmasin. The research methods of analytical survey with cross sectional approach. The population of the research the entire families who have a toddler and are in the work-area Clinics Pekauman Banjarmasin as much as 44 heads of families, with a sampling Technique using Total Sampling. Bivariat analysis results obtained $\mathrm{p}$ value $=0.000$ means that there is a relationship between the density of occupancy with the incidence of respiratory tract infections and there is a p value $=0.000$ means there is a connection between a healthy home with Genesis respiratory tract infections. Conclusion there is a residential density relationships and healthy homes with the incidence of respiratory tract infections.
\end{abstract}

Keywords: Residential Density, the incidence of respiratory tract infections, toddler, healthy Home. 


\section{Introduction}

The situation of Indonesian society in the future or vision to be achieved through health development is formulated as "healthy Indonesia 2025". Conducive environment is a strategic environment in the development of health that is expected by Indonesia Sehat 2025, for the realization of physical, spiritual and social conditions, namely the environment that is free from social insecurity and Pollution, availability of adequate drinking water and environmental sanitation facilities, healthy housing and settlements, the planning of healthoriented areas, and the realization of the lives of people who have social solidarity by maintaining Cultural values of the nation [1].

The expected public behavior in Indonesia Sehat 2025 is a proactive behaviour to maintain and improve health by preventing the risk of disease, protecting yourself from disease threats and problems Health, legal conscious, and actively participating in public health movements, including organizing a healthy and safe community [1].

Indonesia Sehat 2025 is expected that the community has the ability to reach quality health services and also obtain health insurance, namely the public to get protection in fulfilling the basic needs of health. The qualified healthcare service is health services including health care in emergencies and disasters, health services that meet the needs of the community and held in accordance with the standards and ethical professions. One of the main objectives also increases the degree of human life especially toddlers by suppressing the number of diseases in infants especially ISPA [1].

Acute respiratory infections (ISPA) is an acute infectious disease that attacks one or more parts of the respiratory tract ranging from the nose to alveoli, such as sinus, middle ear cavity and pleural. ISPA is still a major health issue that is widely found in Indonesia. This is due to the high mortality rate due to ISPA especially in infants and toddlers. Acute respiratory tract infection (ISPA) is a very common disease and is the cause of the highest death in children of infants. Genesis ISPA is influenced by many factors especially nutritional status [2].

ISPA adalah penyakit infeksi saluran pernafasan ibuhexal yang meliputi infeksi saluran pernafasan atas yang ditandai dengan gejala demam, pilek, batuk, radang tenggorokan, serta infeksi telinga [3].

The World Health Organization (WHO) estimates the incidence of acute respiratory infections (ISPA) in developing countries with toddler mortality rates above 40 per 1000 live births is $15 \%-20 \%$ annually at the age of toddlers. Based on the prevalence of ISPA in 2016 Indonesia has reached $25 \%$ with the incidence range of about $17.5 \%-41.4 \%$ with 16 provinces of which have a prevalence above national figures, in addition ISPA also often on the list of 10 diseases Most in the hospital [4].

The mortality survey conducted by Subdit ISPA in 2016 placed ISPA as the cause of the biggest infant death in Indonesia with a percentage of $32.10 \%$ of all infant deaths.) Acute respiratory infections reached the first 10 outpatient disease in the 2017 hospital in the year and ranks ninth out of the 10 major hospital hospitalizations of the year 2017. This is suspected because this disease includes a strong illness and the quality of its treatment is not adequate, while for the region of South Kalimantan in 2017, noted 11,012 children are experiencing the risk of ISPA [1].

The World Health Organization body of the United Nation International Children Emergency Fund (UNICEF) or the World Health Organization (WHO) dubbed The ISPA as 
"The forgotten killer of children", a forgotten child killer. In developing countries $60 \%$ of ISPA cases are caused by bacteria, while in developed countries are generally caused by viruses. In 2013, the WHO estimated 1.6 million children died from the problem of acute respiratory infections (ISPA) and also assumed a $28 \%$ portion as a leading cause of infant death in Indonesia. The incidence of ISPA in toddlers in Indonesia in 2013 was 390,319 cases $(22.18 \%)$, in 2014 with the number of cases found as many as 642,700 cases $(29.12 \%)$ [5].

Yusup and Susistyorini (2005), argue that houses that do not meet health requirements such as humidity, temperature and natural lighting are not qualified can be a good environment for the development of ISPA bacteria and the transmission of ISPA disease In toddlers [6]. Toddlers have immune systems that are still susceptible to disease including ISPA [4].

Data from the Banjarmasin City Health Office The number of toddlers (year 2017) as much as 32,258 people. In the area of Banjarmasin East ISPA case as much as 1,425 cases (4.4\%), North Banjarmasin ISPA cases as many as 1,539 cases (4.7\%), West Banjarmasin ISPA cases as much as 4,258 cases $(13.1 \%)$ and South Banjarmasin ISPA cases as much as 5,023 cases $(15.6 \%)$ [7].

Pekauman Puskesmas is one of the puskesmas in the area of South Banjarmasin with an area of 7 KM2. The most cases of ISPA based on sick toddler cohort in Pekauman Puskesmas (2017) came from Kelurahan Kelayan Selatan. RT 13 is the most area that has a toddler 41 KK and has an ISPA event record in the most toddlers as many as 328 events within a year.

Preliminary study results conducted on 16-18 January 2018 are known that from 10 houses inhabited by 10 families, 6 houses are inhabited by more than one family, because they are living with their parents or in-laws, as well as staying with Relatives and other families.

The goal that can be expected from this research is to analyze the density of residential and healthy home relations with the incidence of ISPA in toddlers in Pekauman Puskesmas working area Banjarmasin.

\section{Materials And Methods}

The study uses analytical survey methods with a cross sectional approach. The population in this research is the whole family who have toddler and are in the work area of Pekauman Puskesmas South Banjarmasin as much as $44 \mathrm{KK}$. The total sampling technique of 44 K.K. RT. 13 Pekauman Puskesmas in Banjarmasin from 30 May to 4 June 2018. How to collect data on this research using checklist list.

\section{Results And Discussion}

Housing density obtained based on the research results presented in table 1:

Table 1. Residential density frequency distribution

\begin{tabular}{ccc}
\hline Residential density & f & $\%$ \\
\hline Solid & 14 & 31,8
\end{tabular}




\begin{tabular}{ccc} 
Not solid & 30 & 68,2 \\
\hline Total & 44 & 100.0 \\
\hline
\end{tabular}

The results showed that from $44 \mathrm{HH}$ respondents whose occupancy density was said to be not solid has the largest amount of 30 HOUSEHOLDS $(68.2 \%)$.

\subsection{Healthy Home}

Healthy homes are obtained based on the research results presented in table 2:

Table 2 Distribution of healthy home frequencies

\begin{tabular}{ccc}
\hline Healthy Home & $\mathrm{f}$ & $\%$ \\
\hline Not eligible & 25 & 56,8 \\
Qualify & 19 & 43,2 \\
\hline Total & 44 & 100.0
\end{tabular}

The results showed that from $44 \mathrm{HH}$, a healthy home respondent who was said to be ineligible has the largest amount of 25 HOUSEHOLDS (56.8\%). Healthy Home Assessment conducted based on 3 Kompunen namely: Home component, sanitary facilities and behavior weight.Kejadian

\subsection{ISPA}

The incidence of ISPA obtained based on the research results presented in table 3:

\begin{tabular}{ccc}
\multicolumn{2}{c}{ Table 3. Frequency distribution of ISPA events: } \\
\hline Genesis ISPA & $\mathrm{f}$ & $\%$ \\
\hline Yes & 23 & 52,3 \\
No & 21 & 47,7 \\
\hline Total & 44 & 100.0
\end{tabular}

The results showed that from $44 \mathrm{KK}$, infants who experienced ISPA had the largest number of 23 people $(52.3 \%)$.

\subsection{Density of residential relations with Genesis ISPA in infants in the working area of Pekauman Puskesmas Banjarmasin}

The results of the research obtained then analyzed using Chi Square analysis of residential density relationship with Genesis ISPA in toddler in Pekauman Puskesmas working area Banjarmasin, presented in table 4 the following:

Table 4. Density of residential relations with Genesis ISPA in infants in the working area of Pekauman Puskesmas Banjarmasin

\begin{tabular}{llllllll}
\hline \multirow{2}{*}{ No } & $\begin{array}{l}\text { Residential } \\
\text { density }\end{array}$ & \multicolumn{2}{c}{ ISPA } & & $\mathrm{f}$ & $\%$ \\
\cline { 2 - 7 } & Ya & $\%$ & Tidak & $\%$ & & \\
\hline
\end{tabular}




\begin{tabular}{|c|c|c|c|c|c|c|c|}
\hline 1 & Solid & 14 & 100 & 0 & 0 & 14 & 100 \\
\hline 2 & Not solid & 9 & 30 & 21 & 70 & 30 & 100 \\
\hline $\mathrm{n}$ & & 23 & 52,3 & 21 & 47,7 & 44 & 100 \\
\hline
\end{tabular}

The results showed that from $44 \mathrm{KK}$, it is known that $\mathrm{KK}$ with a dense residential with a toddler who has an ISPA amounting to 14 people (100\%).

Results of analysis with Chi Square test obtained the result that the value $\mathrm{P}=0,000<\alpha=$ 0.05 or can be said that there is a relationship of residence density with Genesis ISPA in infants in the work area Pekauman Puskesmas Banjarmasin.

\subsection{Healthy home relations with Genesis ISPA in infants in the working area of Pekauman Puskesmas Banjarmasin}

The results of research obtained then analyzed using the chi Square analysis test about healthy home relations with Genesis ISPA in infants in the workplace of Pekauman Puskesmas Banjarmasin, presented in table 5 follows:

Tabel 5. Healthy home relations with Genesis ISPA in infants in the working area of Pekauman Puskesmas Banjarmasin

\begin{tabular}{|c|c|c|c|c|c|c|c|}
\hline \multirow{2}{*}{ No } & \multirow{2}{*}{ Rumah Sehat } & \multicolumn{4}{|c|}{ ISPA } & \multirow{2}{*}{$\mathrm{f}$} & \multirow{2}{*}{$\%$} \\
\hline & & $\mathrm{Ya}$ & $\%$ & Tidak & $\%$ & & \\
\hline 1 & Not eligible & 22 & 88 & 3 & 12 & 25 & 100 \\
\hline \multirow[t]{3}{*}{2} & Qualifier & 1 & 5,3 & 18 & 94,7 & 19 & 100 \\
\hline & $\mathrm{n}$ & 23 & 52,3 & 21 & 47,7 & 44 & 100 \\
\hline & \multicolumn{7}{|c|}{$\mathrm{p}$ value $=0,000(\alpha=0,05)$} \\
\hline
\end{tabular}

The results showed that from 44 it was known that a healthy home that was not eligible with a toddler who had an ISPA amounted to 22 people $(88 \%)$. Results of analysis with the Chi Square test obtained the result that the value $\mathrm{P}=0,000<\alpha=0.05$ or can be said that there is a healthy home relationship with Genesis ISPA on toddlers in the work area Pekauman Puskesmas Banjarmasin.

\section{Discussion}

Discussion of univariic Data analysis test results

\subsection{Overview of the density of residential in Pekauman district Puskesmas Banjarmasin}

The results showed that from $44 \mathrm{HH}$ respondents whose occupancy density was said to be not solid has the largest amount of 30 HOUSEHOLDS (68.2\%) And respondents whose occupancy density is said to have the smallest number of 14 people $(31.8 \%)$.

Houses that are much inhabited without a balanced area will result in reduced indoor oxygen and not meeting all family members. Dense dwelling can also increase the temperature 
of the room so that the room feels efficient and hot due to moisture and heat temperature generated by the body of the occupants that means more and more occupants in a house can increase Faster displacement of viruses and bacteria either by touch or by air. It is in agreement with Widoyono (2008), which states that the ISPA episodes on toddlers in Indonesia averaged 4 times per year with fever symptoms accompanied by a cold cough [8].

The theory of epidemiological Egitas explains that there are three factors affecting the incidence of a disease, namely the medicine, disease and environment. In this case the role of parents is very important in maintaining the immunity of toddlers so as not easily exposed to ISPA by providing food with balanced nutrition, in addition, parents should also maintain the environmental condition of home especially physical sanitation of the home Stay safe and healthy for toddlers [9].

The results of this study were in line with the research by Putra (2011) indicating that from $45 \mathrm{KK}$, as many as $30 \mathrm{KK}(66.7 \%)$ Not belong to the category of solid occupancy as most of the KK consist of a core family (father, mother and 1 to 2 children only) [10].

\subsection{Overview of healthy homes in the work area of Pekauman Puskesmas Banjarmasin}

The results showed that from $44 \mathrm{HH}$ respondents who were said to be ineligible have the largest number of 25 HOUSEHOLDS (56.8\%) And healthy home respondents who are said to be eligible have the smallest number of 19 people (43.2\%).

The results showed that from $44 \mathrm{KK}$ respondents the home component that is said to be ineligible has the largest amount of 34 HOUSEHOLDS (77.3\%). Some families live in a plot house, which among the other houses has one roof and one wall, while some houses use zinc walls and do not have a house ceiling that serves as a Direct solar heat barrier delivered by zinc.

The results showed that from $44 \mathrm{KK}$ respondents of sanitation facilities that are said to be ineligible have the largest amount of $30 \mathrm{KK}(68.2 \%)$. Some houses do not have a WC in the house and for the purposes of the chapter, residents use the latrines together and almost all citizens say to BAK them at home by way of Bak in the kitchen on the floor that has been given holes, besides Residents also do not have waste sewer such as GOT and others so that the household waste impurities are discharged directly to the hole in the kitchen floor and it is not uncommon to cause unpleasant odor and trigger the emergence of Dirty animals like flies, mosquitoes, rats and so forth.

The results showed that from 44 , the respondents were said to be unfulfilled and qualified to have the same number of $22 \mathrm{KK}(50.0 \%)$. Some respondents did not have the bedroom window thus affecting the results of home behavior in variables opening the bedroom window. In addition, bad tenant behaviour also occurs in respondents who have bedroom windows with some reasons, such as worrying about the incoming theft, mosquitoes enter the room, the distance of each adjacent house so that they Tends not to open the bedroom window every day.

The results were in line with the study by Sukarto (2016) which shows that from $50 \mathrm{KK}$, as many as $38 \mathrm{KK}(76 \%)$ is said to be ineligible as a healthy home [4].

\subsection{ISPA Event Overview In toddlers in Pekauman Puskesmas in Banjarmasin}

The results showed that from $44 \mathrm{KK}$, infants who experienced ISPA had the largest number of 23 people $(52.3 \%)$ and toddlers who do not experience ISPA have the smallest number of 21 people $(47.7 \%)$. 
Many toddlers who experience ISPA due to unconducive and erratic weather. The baby's body resistance that is still lacking causes the baby to be infected with a variety of diseases, especially ISPA. In addition, the less clean environment and cleanliness of the toddler is not maintained to trigger the occurrence of ISPA, other than that the residence shelter can also cause toddlers to easily attack the ISPA, either through viruses brought or transmitted by Other family members or from less clean and unhealthy home conditions.

The WHO (2007), stated that ISPA was one of the diseases that were contaging through the air. Based on this, the toddler who has a house with an area of ventilation that does not comply with health requirements will be at risk of experiencing ISPA. Thus, in order to prevent such risks, the elderly children with ventilation areas that do not comply with health requirements or do not even have air ventilation need to add or make air ventilation so that air circulation can occur [11].

Bivariate Data Analysis Test results

\subsection{Density of residential relations with Genesis ISPA in infants in the working area of Pekauman Puskesmas Banjarmasin}

The results showed that from $44 \mathrm{KK}$, it was revealed that $\mathrm{KK}$ with a dense residence with a toddler who experienced an ISPA amounted to 14 people (100\%). Results of analysis with Chi Square test obtained the result that the value $\mathrm{P}=0,000<\alpha=0.05$ or can be said that there is a relationship of residence density with Genesis ISPA in infants in the work area Pekauman Puskesmas Banjarmasin.

This is caused by a house that is crowded by the occupants causing the ease of family members infected with a wide range of viruses one of which is a virus that can cause ISPA especially toddlers who have a less immune system. The more family members stay in the house but are not balanced with the house, the faster the virus transfer from one person to another.

The results showed that most families with solid residential educated high school (as much as 9 people/31,1\%) and working as a trader (as much as 7 people/46,7\%). The education of a family head that is limited to secondary education is difficult for the head of the family to get a much more decent job with higher income so as to provide a good residence for the family. In addition, the work of the family head as a trader amid high entrepreneurial competition that makes the family head erratic and is quite fitting to meet the needs of life for family and himself.

The results of this study are in line with the research by Sukarto (2016) which suggests that there is a residential density relationship with the incidence of ISPAH on infants $(\mathrm{p}=$ 0,$000 ;<0.05$ ) [4]. The density of home dwellers can also affect the health, because if a house whose inhabitants are dense can allow the occurrence of disease transmission from one human to another. The density of excessive indoor occupants will have an effect on the development of indoor seedlings. Life density in the home is one of the factors that can increase the incidence of ISPA disease and other infectious diseases.

\subsection{Healthy home relations with Genesis ISPA in infants in the working area of Pekauman Puskesmas Banjarmasin}

The results showed that from 44 it was known that a healthy home that was not eligible with a toddler who had an ISPA amounted to 22 people $(88 \%)$. Results of analysis with Chi Square test obtained the result that the value $\mathrm{P}=0,000<\alpha=0.05$ or can be said that there is a 
healthy home relationship with Genesis ISPA on toddlers in the work area Pekauman Puskesmas Banjarmasin.

The results showed that most families with healthy homes were not eligible for high school education (as much as 23 people/100\%) and working as a labour (as much as 16 people/100\%). Home of some residents in RT. 13 is a wooden house that does not have a ceiling, some houses use zinc as a wall of the house that can add to the heat of the room Waste, using the latrines used by some residents together, there is no green plants either in the house or the house is found and some houses have a cage that is placed exactly beside or behind the house.

Health officers can provide counseling as an educator for the community to always maintain and care for the house to meet the classification of healthy homes without the need to cost expensive such as diligent cleaning the house at least 1-2 times a day in a way Sweep and mop the floor and wipe glass and dust, dispose of garbage in place, prevent the presence of water and close the meeting of water shelters, planting greenery or inside the house, have adequate air ventelation and functioning Well, opening the window so that sunlight can enter partly during the night as well as avoid cattle or animals that can cause a variety of diseases vector from home.

\section{References}

[1] Kemenkes RI. Bahaya ISPA Bagi Bayi dan Balita. Jakarta. Direktorat Kementrian Kesehatan Indonesia. 2017.

[2] Ranuh, I. Masalah ISPA dan Kelangsungan Hidup Anak. Jakarta: Continuing Education. 2014.

[3] Oktaviani, V., A. Hubungan antara Sanitasi Fisik Rumah dengan Kejadian Infeksi Saluran Pernafasan Atas (ISPA) pada Balita di Des Cepogo Kecamatan Cepogo Kabupaten Boyolali. Sukoharjo: Universitas Muhammadiyah Surakarta. Diakses 26 April 2018]. (2009).

[4] Sukarto, RCW. Hubungan Peran Orang Tua dalam Pencegahan ISPA dengan kekambuhan ISPA pada balita di Puskesmas Bilalang Kota Kotamobagu. e-Journal Keperawatan e-Kp Volume 4 Nomor 1, Mei 2016 [internet]. Tersedia pada:https://media.neliti.com/media/publications/114343-ID-hubungan-peran-orang-tuadalam-pencegaha.pdf. [Diakses 26 April 2018]. 2016.

[5] Lebuan, SW. Faktor Yang Berhubungan Dengan Infeksi Saluran Pernapasan Akut Pada Siswa Taman Kanak-Kanak Di Kelurahan Dangin Puri Kecamatan Denpasar Timur. EJurnal Medika, Vol. 6 No. 6 Juni 2017 Denpasar: Fakultas Kedokteran Universitas Udayana. [internet]. Tersedia pada: https://ojs.unud.ac.id/index.php/eum/article/view/31485. [Diakses 26 April 2018]. 2017.

[6] Yusup. N. A dan L. Sulistyorini. Hubungan Sanitasi RUmah Secara Fisik dengan Kejadian ISPA pada Balita. IJurnal Kesehatan Lingkungan, Vol 1[2]: 110-119. Diakses dari http://journal.unair.ac.id/. 2015.

[7] Data dan Informasi Profil Kesehatan Indonesia 2016. Jakarta. Direktorat Kementrian Kesehatan Indonesia.

[8] Widoyono. Penyakit Tropis Epidemiologi, Penularan, Pencegahan dan Pemberantasannya. Jakarta: Penerbit Erlangga. 2008.

[9] Agungnisa A. Faktor Sanitasi Fisik Rumah yang berpengaruh terhadap kejadian ISPA pada Balita di Desa Kalianget Timur. Jurnal Kesehatan Lingkungan. Vol. 11 No. I (di akses 26 April 2018). 2017. 
[10] Putra. Keperawatan Ana k dan Tumbuh Kembang. Yogyakarta: Nuha Medika. 2011.

[11] WHO. Pedoman Interm WHO: Pencegahan dan pengendalian infeksi saluran pernafasan akut (ISPA) yang cenderung menjadi epidemi dan pandemic di fasilitas pelayanan kesehatan (Trust Indonesia, Penerjemah). Geneva: WHO. DIakses dari http://apps.who.int/.2007. 
